\title{
Screening and quantification of anti-quorum sensing and antibiofilm activities of phyllosphere bacteria against biofilm forming bacteria
}

\author{
Nadine Amabel Theodora, Vania Dominika and Diana Elizabeth Waturangi
}

\begin{abstract}
Objective: The objectives of this research were to screen anti-quorum sensing activity of phyllosphere bacteria and quantify their antibiofilm activity against biofilm forming bacteria (Bacillus cereus, Staphylococcus aureus, Enterococcus faecalis, Salmonella typhimurium, Vibrio cholerae, Pseudomonas aeruginosa).

Results: We found 11 phyllosphere bacteria isolates with potential anti-quorum sensing activity. Most of the crude extracts from phyllosphere bacteria isolates had anti-quorum sensing activity against Chromobacterium violaceum at certain concentration (20 and $10 \mathrm{mg} / \mathrm{mL}$ ), but not crude extract from isolate JB 7F. Crude extract showed the largest turbid zone $(1,27 \mathrm{~cm})$ using isolate $J B 14 B$ with concentration of $10 \mathrm{mg} / \mathrm{mL}$ and the narrowest turbid zone isolate $(1 \mathrm{~cm})$ using JB 18B with concentration of $10 \mathrm{mg} / \mathrm{mL}$. Crude extracts showed various antibiofilm activities against all tested pathogenic bacteria, it showed the highest biofilm inhibition (90\%) and destruction activities (76\%) against $\mathrm{S}$. aureus.
\end{abstract}

Keywords: Antibiofilm activity, Chromobacterium violaceum, Phyllosphere, Quorum sensing, Violacein

\section{Introduction}

Nowadays, we know that about $65 \%$ of all bacterial infections were associated with bacterial biofilms [1]. Biofilm is an organized aggregate of microorganisms like bacteria within an extracellular polymeric matrix that they produce $[1,2]$. Several pathogenic bacteria form a biofilm using a mechanism called quorum sensing. Quorum sensing is a communication form among bacteria by various types of extracellular signal molecules called autoinducer (AI). Bacteria in biofilm were more resistant to antibiotic because biofilm matrix can help with interfering the penetration of antibiotic. Therefore we need to explore compound that have capability to inhibit or destroy biofilm as well as anti-quorum sensing to control attack of biofilm-forming pathogenic bacteria [3].

*Correspondence: Diana.waturangi@atmajaya.ac.id

Faculty of Biotechnology, Atma Jaya Catholic University of Indonesia,

Jenderal Sudirman 51 Street, South Jakarta, 12930 DKI Jakarta, Indonesia
Phyllosphere bacteria, which lives the most on the leaves surface area, reported to have potential in quorum quenching activity with produce molecules such as AHL lactonase enzyme [4-6]. High populations of phyllosphere bacteria show activities such as antimicrobial and antibiofilm that produced to survive on the leaves surface area [7]. Many research have been conducted to analyze anti-quorum sensing activity from phyllosphere bacteria. The objectives of this research were to screen anti-quorum sensing activity of phyllosphere bacteria using Chromobacterium violaceum as indicator bacteria and quantify their antibiofilm activity against biofilm forming bacteria (Bacillus cereus, Staphylococcus aureus, Enterococcus faecalis, Salmonella typhimurium, Vibrio cholerae, Pseudomonas aeruginosa).

\section{Main text \\ Methods \\ Bacterial cultivation}

The phyllosphere bacteria were from Atma Jaya Catholic University of Indonesia culture collections in 
cryopreservation. These bacteria were from previous research and recovered from Psidium guajava, Averrhoa carambola, and Anredera cordifolia leaves [8, 9]. Bacteria were grown in Luria-Bertani Agar (LA) and were incubated at $28{ }^{\circ} \mathrm{C}$ for $48 \mathrm{~h}$. After that, single colony was picked and grown in King's B medium and incubated at $28{ }^{\circ} \mathrm{C}$ for $48 \mathrm{~h}$.

Pathogenic bacteria used were B. cereus ATCC 14579, S. aureus ATCC 29213, E. faecalis ATCC 33186, P. aeruginosa ATCC 27853, S. typhimurium, V. cholerae. All pathogenic bacteria were from cryopreservation and were streaked onto LA then incubated $37^{\circ} \mathrm{C}$ overnight.

\section{Primary screening of anti-quorum sensing activity}

The monitor strain $C$. violaceum was grown separately in $50 \mathrm{~mL}$ of LB broth medium and incubated at $28{ }^{\circ} \mathrm{C}$, $120 \mathrm{rpm}$ for $48 \mathrm{~h}$. Phyllosphere bacteria were streaked onto LA in a straight line then incubated at $28^{\circ} \mathrm{C}$ for $24 \mathrm{~h}$. After that, $100 \mu \mathrm{L}$ of monitor strain $\left(\mathrm{OD}_{600}=0.132\right)$ were put into $2 \mathrm{~mL}$ semisolid agar $(0.75 \%$ agar) for overlay on top of the phyllosphere isolates which had been streaked before. These plates were incubated at $28{ }^{\circ} \mathrm{C}$ overnight. A positive result indicated by inhibiting violacein pigmentation (opaque zone) of the $C$. violaceum around the streak of the phyllosphere isolates [10].

\section{Production of crude extract}

Isolates that had given positive result from the primary screening of anti-quorum sensing activity were extracted by using liquid-liquid extraction. The bacterial culture were inoculated into $100 \mathrm{~mL}$ of Luria-Bertani Broth (LB) then incubated in orbital shaker incubator at $28{ }^{\circ} \mathrm{C}$ for $48 \mathrm{~h} 120 \mathrm{rpm}$. After that, centrifuged at $13,888 \times g$ for $15 \mathrm{~min}$ and cell-free supernatant was harvested and mixed with an equal volume of ethyl acetate. The solvent layer was harvested and evaporated in a rotary evaporator. After that, extract evaporated in an oven vacuum overnight to obtain the crude extract. To this, $1 \%$ of Dimethyl Sulfoxide (DMSO) will be added to obtain a final concentration of 5,10 , and $20 \mathrm{mg} / \mathrm{mL}$ stock (w/v) and kept at $-20{ }^{\circ} \mathrm{C}$ [11].

\section{Antibacterial activity assay}

The crude extracts that had been obtained were tested against pathogenic bacteria such as B. cereus, E. faecalis, and S. aureus, P. aeruginosa, S. typhimurium, and $V$. cholerae using agar well diffusion method. Pathogenic bacteria were streaked continuously on Brain Heart Infusion Agar (BHIA). Then, the extracts were applied $50 \mu \mathrm{L}$ of 5,10 , and $20 \mathrm{mg} / \mathrm{mL}$ solution to the well. Streptomycin (Merck; $10 \mathrm{mg} / \mathrm{mL}$ ) were used as positive control, whereas DMSO was used as negative control. The plates were incubated at $37{ }^{\circ} \mathrm{C}$ for $24 \mathrm{~h}$. This assay was performed in triplicate [12].

\section{Detection of anti-quorum sensing activity}

The crude extracts were tested for anti-quorum sensing activity against $C$. violaceum by agar well diffusion method. C. violaceum was streaked on LA with a sterile cotton swab. Then the extracts $(50 \mu \mathrm{L})$ with various concentration $(5,10$, and $20 \mathrm{mg} / \mathrm{mL})$ were applied to the well. DMSO was used as a control. The plates were incubated at $28^{\circ} \mathrm{C}$ for $24 \mathrm{~h}$. Anti-quorum sensing activity was observed through a turbid halo zone against a background of violacein pigment. This assay was performed in triplicate [10].

\section{Quantification of antibiofilm activity}

The pathogenic bacteria were inoculated into BHIB and incubated overnight. After that, for biofilm inhibition test, $100 \mu \mathrm{L}$ of crude extracts and $100 \mu \mathrm{L}$ of bacterial cultures $\left(\mathrm{OD}_{600}=0.132\right)$ were transferred into 96-well microtiter plates (polystyrene) then incubated at $37{ }^{\circ} \mathrm{C}$ for $24 \mathrm{~h}$. Meanwhile for biofilm destruction test, $100 \mu \mathrm{L}$ of bacterial culture were transferred into 96-well microtiter plates then incubated. After that, $100 \mu \mathrm{L}$ of crude extracts will be added and incubated at $37{ }^{\circ} \mathrm{C}$ for $24 \mathrm{~h}$. Then planktonic cells and media were discarded. Adherent cells were rinsed gently twice with distilled water and allowed to air dry. The biofilms were stained by $200 \mu \mathrm{L}$ of $0.4 \%(\mathrm{w} / \mathrm{v})$ crystal violet solution for $30 \mathrm{~min}$. After that, the dye were discarded and the wells were rinsed twice with distilled water. The wells were air dried and then $200 \mu \mathrm{L}$ of ethanol were used to solubilize the crystal violet. The optical density were determined at $595 \mathrm{~nm}$ using a microplate reader. BHIB was used as blank and bacterial cultures without extracts were used as control. This test was performed triplicate [13].

$$
\begin{aligned}
& \text { Percentage biofilm inhibition } \\
& =\frac{(\text { Control OD595 - Treated OD595) }}{(\text { Control OD595) }} \times 100 \%
\end{aligned}
$$

\section{Microscopic observations}

This step was done using Scanning Electron Microscope (SEM) at Dexa Laboratories of Biomolecular Sciences. First, B. cereus and S. typhimurium were grown in BHIB and incubated overnight. Then, bacteria were spotted to a steril cover glass and incubated overnight to form biofilm. After that, crude extracts were spotted into the biofilm and incubated at $37{ }^{\circ} \mathrm{C}$ overnight. At the last step, the results were analyzed using SEM at DLBS [14]. 


\section{Results}

\section{Primary screening of anti-quorum sensing activity}

There were 11 out of 60 phyllosphere isolates from previous study showed an anti-quorum sensing activity. Those positive isolates were extracted and continued to the next step.

\section{Antibacterial activity assay}

From this assay, we know that 1 out of 11 positive phyllosphere isolates crude extract, EJB 7B, showed antibacterial activity against all Gram positive pathogenic bacteria which used in this research. Meanwhile, control positive (Streptomycin) showed various turbid zone depending on the pathogen bacteria used. Average clear zone $V$. cholerae is $2 \mathrm{~cm}, P$. aeruginosa is $3 \mathrm{~cm}, S$. typhimurium is $2.3 \mathrm{~cm}$. Average clear zone $B$. cereus is $4 \mathrm{~cm}, S$. aureus is $3.5 \mathrm{~cm}$, E. faecalis is $3 \mathrm{~cm}$.

\section{Table 1 Result of detection of anti-quorum sensing activity}

\begin{tabular}{|c|c|c|c|c|}
\hline \multirow{2}{*}{$\begin{array}{l}\text { Phyllosphere } \\
\text { isolates }\end{array}$} & \multirow[t]{2}{*}{ Origin of isolates } & \multicolumn{3}{|c|}{ Concentrations $(\mathrm{cm})$} \\
\hline & & $5 \mathrm{mg} / \mathrm{mL}$ & $10 \mathrm{mg} / \mathrm{mL}$ & $20 \mathrm{mg} / \mathrm{mL}$ \\
\hline$J B 3 B$ & Psidium guajava & 0 & 0 & 0.83 \\
\hline $\mathrm{JB} 11 \mathrm{~B}$ & Psidium guajava & 0 & 0 & 1.13 \\
\hline JB 14B & Psidium guajava & 0 & 2 & 1.1 \\
\hline JB 15B & Psidium guajava & 0 & 0 & 1.4 \\
\hline$J B 16 B$ & Psidium guajava & 0 & 0 & 1.27 \\
\hline JB 18B & Psidium guajava & 0 & 1 & 1.2 \\
\hline$J B 19 B$ & Psidium guajava & 0 & 0 & 1.07 \\
\hline JB 20B & Psidium guajava & 0 & 1.2 & 1.7 \\
\hline AF3 & Anredera cordifolia & 0 & 0 & 1.1 \\
\hline JB 7F & Psidium guajava & 0 & 0 & 0 \\
\hline
\end{tabular}

\section{Detection of anti-quorum sensing activity}

We found out that each of phyllosphere isolate has their own optimal concentrations but most of them showed activity at concentration of $20 \mathrm{mg} / \mathrm{mL}$ and all of them have no activity at concentration of $5 \mathrm{mg} / \mathrm{mL}$ Crude extract showed the largest turbid zone $(1.27 \mathrm{~cm})$ using isolate JB 14B with concentration of $10 \mathrm{mg} / \mathrm{mL}$ and the narrowest turbid zone isolate $(1 \mathrm{~cm})$ using JB 18B with concentration of $10 \mathrm{mg} / \mathrm{mL}$ (Table 1 ).

\section{Quantification of biofilm activity}

According to the result of quantification of biofilm (inhibition) activity assay, the results showed that crude extracts had various inhibition activity against all pathogenic bacteria used in this study, with the most positive results against $S$. aureus and the least against $P$. aeruginosa. (Table 2). Crude extracts that showed the highest biofilm inhibition activity against S. aureus (90\%) is from isolate JB 19B.

Meanwhile, different results were obtained from quantification of biofilm (destruction) activity assay. According to biofilm destruction activity data (Table 2), the results showed that crude extracts had various destruction activity against all pathogenic bacteria used in this study, with the most positive results against $S$. aureus and $E$. faecalis and the least against $P$. aeruginosa (Table 2). Crude extracts showed the highest biofilm destruction activity against $S$. aureus (76\%) using isolate JB 18B.

\section{Microscopic observations}

Regarding the results of biofilm destruction we can determined morphological changing, which destruction

Table 2 Results of biofilm activity quantification against pathogenic bacteria

\begin{tabular}{|c|c|c|c|c|c|c|c|c|c|c|c|c|}
\hline \multirow[t]{2}{*}{ Pathogens } & \multirow[t]{2}{*}{ Activity } & \multicolumn{10}{|c|}{ Isolates activity (\%) } & \multirow[b]{2}{*}{ EJB 7B } \\
\hline & & JB 3B & JB 11B & JB 14B & JB 15B & JB 16B & JB 18B & JB 19B & JB 20B & AF3 & JB 7F & \\
\hline \multirow[t]{2}{*}{ S. aureus } & Inhibition & 87 & 61 & 67 & 80 & 72 & 65 & 90 & 58 & 35 & 86 & $x$ \\
\hline & Destruction & 73 & 74 & 0 & 72 & 62 & 76 & 59 & 65 & 23 & 2 & $x$ \\
\hline \multirow[t]{2}{*}{ E. faecalis } & Inhibition & 19 & 0 & 42 & 0 & 0 & 27 & 0 & 0 & 0 & 0 & $x$ \\
\hline & Destruction & 56 & 4 & 54 & 71 & 35 & 64 & 45 & 23 & 37 & 0 & $x$ \\
\hline \multirow[t]{2}{*}{ B. cereus } & Inhibition & 67 & 30 & 0 & 42 & 58 & 0 & 0 & 34 & 0 & 0 & $x$ \\
\hline & Destruction & 45 & 55 & 0 & 26 & 10 & 23 & 9 & 9 & 0 & 0 & $x$ \\
\hline \multirow[t]{2}{*}{ V. cholerae } & Inhibition & 87 & 0 & 14 & 0 & 56 & 18 & 0 & 80 & 0 & 0 & 63 \\
\hline & Destruction & 71 & 72 & 0 & 58 & 59 & 48 & 73 & 0 & 0 & 0 & 0 \\
\hline \multirow[t]{2}{*}{ S. typhimurium } & Inhibition & 29 & 8 & 37 & 21 & 33 & 0 & 0 & 27 & 8 & 0 & 5 \\
\hline & Destruction & 0 & 4 & 0 & 11 & 11 & 0 & 23 & 9 & 15 & 2 & 12 \\
\hline \multirow[t]{2}{*}{ P. aeruginosa } & Inhibition & 68 & 0 & 0 & 0 & 0 & 0 & 0 & 0 & 0 & 0 & 0 \\
\hline & Destruction & 20 & 4 & 0 & 0 & 0 & 0 & 23 & 0 & 0 & 0 & 0 \\
\hline
\end{tabular}

$\mathrm{X}$ : no test was performed 
a

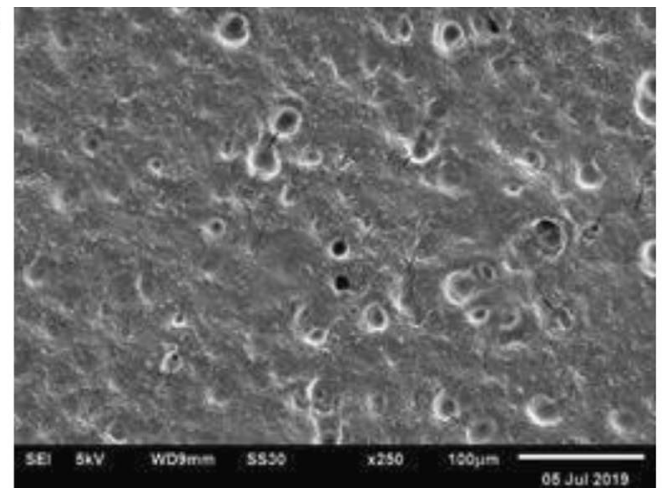

b

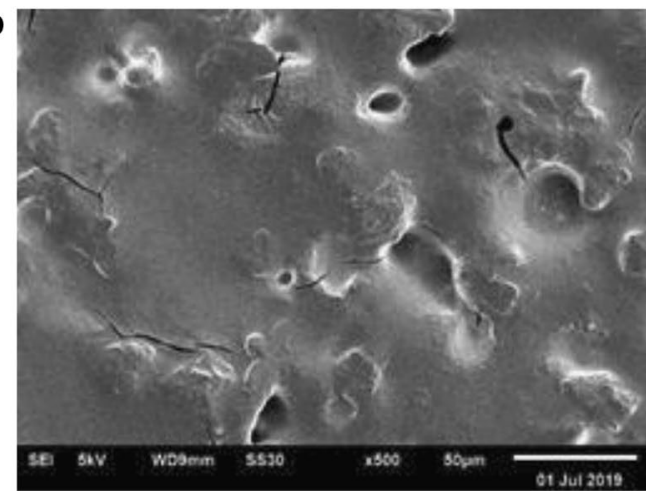

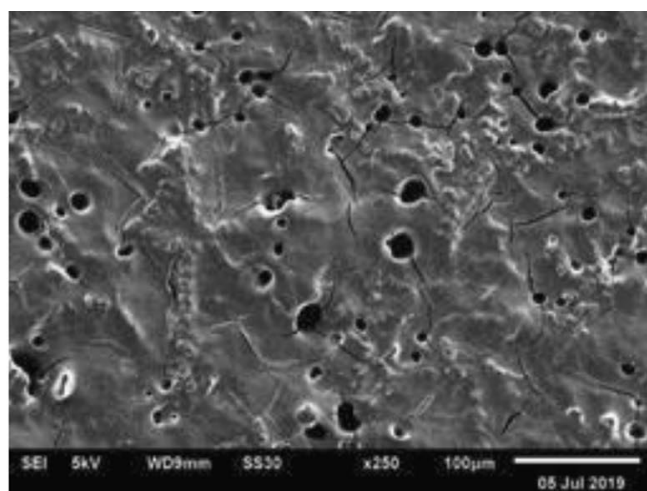

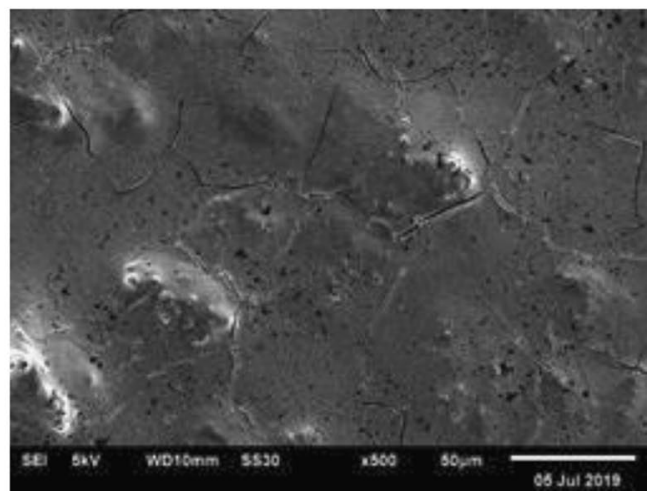

Fig. 1 SEM images of S. typhimurium biofilm destruction by extract of isolate JB $19 B$ with $(\mathbf{a})$ pathogen control and (b) control + extract $(\times 250)$ and Bacillus cereus biofilm destruction by extract of isolate JB 18B with (a) pathogen control and (b) control + extract $(\times 500)$

activity of extract from isolate JB 18B and JB 19 B against mature biofilm of B. cereus and S. typhimurium.

\section{Discussion}

Based on primary screening of anti-quorum sensing activity results, we found 11 out of 60 phyllosphere isolates were potential to be used as anti-quorum sensing agent. It might be happened because phyllosphere bacteria need survival strategy in the stressful environment due to the fluctuations in physical conditions and limited and highly heterogenous availability of nutrients [15].

Based on antibacterial activity assay result, we found that only isolate EJB 7B extract had antibacterial activity against Gram positive-biofilm forming bacteria. The result showed that most of them had no bactericidal activity towards biofilm-forming pathogenic bacteria which is would not lead to antibiotic resistance [10].

Based on the results, at $5 \mathrm{mg} / \mathrm{mL}$ concentration all of the phyllosphere extracts have no activity. It might be due to because the concentration were relatively small. JB 7F extract showed no activity at any concentrations because it needed higher concentration for quorum quenching activity. In this study, inhibition of violacein pigments could happened because AHL from $C$. violaceum were degraded by metabolites that produce by phyllosphere bacteria [16]. We also can conclude that quorum quenching activity is affected by bacteria producer and extract concentration that we used [10].

Biofilm is a cell function whose gene expression is regulated by quorum sensing $[17,18]$. Therefore, quorum quenching mechanisms might be a good alternative to overcome biofilm problems [19]. Based on quantification of biofilm activity both in inhibition and destruction steps (Table 2), these extracts showed various results. The biofilm inhibition activity might happen because quorum sensing process of pathogenic bacteria was disturbed by interfering autoinducer synthesis, cell to cell exchange, autoinducer's reception and transduction, and degrading autoinducer $[7,20]$.

The biofilm destruction activity might be the result of enzyme that could hydrolyze the compound of biofilm or small molecule that induce biofilm destruction [21]. EPS composition of pathogenic bacteria biofilms were diverse depending on the bacteria [22]. Various EPS compounds can be degraded by specific enzymes like proteases, deoxyribonucleases, glycoside hydrolase [23].

From SEM analysis, we can determine morphological changing which showed destruction activity (Fig. 1). It indicated there is reduction of extracellular matrix and this result approved quantification of antibiofilm assay 
[14]. Therefore, phyllosphere bacteria extract such as JB $18 \mathrm{~B}$ and JB 19B can destruct biofilm of pathogenic bacteria like B. cereus and S. typhimurium.

\section{Conclusion}

JB 3B isolate has a broad spectrum antibiofilm activity both in inhibition and destruction ways because it can inhibit and destruct almost all biofilm of pathogenic bacteria that are used in this study. So far crude extracts of phyllosphere isolates are potential to be used as quorum quenching and antibiofilm agents against some of biofilmforming pathogenic bacteria used in this study. For future research it might be possible to sequence the phyllosphere bacteria metabolites so we can know what kind of quorum quenching agents that phyllosphere bacteria has.

\section{Limitation}

This research did not know kind of molecule in the phyllosphere bacteria extract and did not look for at least genus of the phyllosphere bacteria.

\section{Abbreviations \\ Al: autoinducer; SEM: scanning electron microscope.}

\section{Acknowledgements}

The authors are grateful toward all the supports and would like to thank everyone who contributed in this study. We also would like to give a big appreciation to Helen Listiarini and Juliana who contributed in sample preparation.

\section{Authors' contributions}

DEW involved in proposal design preparation. VD and NAT prepared proposal writing, data analysis and manuscript preparation under advisory of DEW. All authors read and approved the final manuscript.

\section{Funding}

This study was funded by DIKTI 2018. The funder has no contribution in design, collection, writing and interpreting data in this study.

\section{Availability of data and materials}

The data of this study is available with the corresponding author up on request.

\section{Ethics approval and consent to participate}

Not applicable.

\section{Consent for publication}

Not applicable.

\section{Competing interests}

The authors declare that they have no competing interests.

Received: 23 September 2019 Accepted: 31 October 2019 Published online: 07 November 2019

\section{References}

1. Jamal M, Ahmad W, Andleeb S, Jalil F, Imran M, Nawaz MA, Hussain T, Ali M, Rafiq M, Kamil MA. Bacterial biofilm and associated infections. JCMA. 2018;81(1):7-11.

2. Hall CW, Mah T. Molecular mechanisms of biofilm-based antibiotic resistance and tolerance in pathogenic bacteria. FEMS Microbiol Rev. 2017:41(3):276-301.
3. Basavaruju M, Sisnity VS, Palaparthy R, Addanki PK. Quorum quenching: signal jamming in dental plaque biofilms. J Dent Sci. 2016;2016(11):349-52.

4. Ma A, Lv D, Zhuang X, Zhuang G. Quorum quenching in culturable phyllosphere bacteria from tobacco. Int J Mol Sci. 2013;2013(14):14607-19.

5. Remus-Emsermann MNP, Schlechter RO. Phyllosphere microbiology: at the interface between microbial individuals and the plant host. New Phytol. 2018;2018(218):1327-33.

6. Satwika TD, Rusmana I, Akhdiya A. Potensi quorum quenching bakteri filosfer dan rizosfer terhadap dickeya dadantii. J AgroBiogen. 2017;13(2):101-10.

7. Zhou J, Bi S, Chen H, Chen T, Yang R, Li M, Fu Y, Jia A. Anti-biofilm and antivirulence activities of metabolites from Plectospaerella cucumerina against Pseudomonas aeruginosa. Front Microbiol. 2017;8(769):1-17.

8. Juliana. Screening of phyllosphere and endophytic microbes producing antibacterial or anti quorum sensing activity from Ageratum conyzoides, Coleus amboinicus, and Psidium guajava [skripsi]. Jakarta (ID): Universitas Katolik Indonesia Atma Jaya; 2011.

9. Listiarini H. Screening for endophytic and phyllosphere microbes with antibacterial activity from Centella asiatica, Mirabilis jalapa, and Averrhoa bilimbi [skripsi]. Jakarta (ID): Universitas Katolik Indonesia Atma Jaya; 2011.

10. Abudoleh SM, Mahasneh AM. Anti-quorum sensing activity of substances isolated from wild berry associated bacteria. Avicenna J Med Biotech. 2017:9(1):23-30.

11. Younis KM, Usup G, Ahmad A. Secondary metabolites produced by marine streptomyces as antibiofilm and anti-quorum sensing inhibitor of uropathogen Proteus mirabilis. Environ Sci Pollut Res. 2015;23(5):4756-67.

12. Tabbouche SA, Gurgen A, Yildiz S, Kilic AO, Sokmen M. Antimicrobial and antiquorum sensing activity of some wild mushrooms collected from Turkey. MSU J Sci. 2017;5(2):453-7.

13. Lokegaonkar SP, Nabar BM. In vitro antibiofilm, antiquorum sensing activity of gamma tolerant streptomyces against Gram negative pathogens. Int J Pharm Clin Res. 2017;9(11):665-70.

14. Luo J, Dong B, Wang K, Cai S, Liu T, Cheng X, Lei D, Chen Y, Kong J, Chen Y. Baicalin inhibits biofilm formation, attenuates the quorum sensing-controlled virulence and enhances Pseudomonas aeruginosa clearance in a mouse peritoneal implant infection model. PLOS ONE. 2017;12(4):e0176883.

15. Hunter PJ, Hand P, Pink D, Whipps JM, Bending GD. Both leaf properties and microbe-microbe interactions influence within-species variation in bacterial population diversity and structure in the lettuce (Lactuca species) phyllosphere. Appl Environ Microbiol. 2010;76(24):8117-25.

16. Stauff DL, Bassler BL. Quorum sensing in Chromobacterium violaceum: DNA recognition and gene regulation by the CviR receptor. ASM. 2011;193(15):3871-8.

17. Biradar B, Devi P. Quorum sensing in plaque biofilms: challenges and future prospects. JCDP. 2011;12(6):479-85.

18. Roy R, Tiwari M, Donelli G, Tiwari V. Strategies for combating bacterial biofilms: a focus on anti-biofilm agents and their mechanisms of action. Virulence. 2018;9(1):522-54.

19. Shah S, Gaikwad S, Nagar S, Kulshretha S, Vaidya V, Nawani N, Pawar S. Biofilm inhibition and anti-quorum sensing activity of phytosynthesized silver nanoparticles against the nosocomial pathogen Pseudomonas aeruginosa. Biofouling. 2019;35(1):1-16.

20. Grandclement C, Tannieres M, Morera S, Dessaux Y, Faure D. Quorum quenching: role in nature and applied developments. FEMS microbiol Rev. 2016:40(1):86-116.

21. You JL, Xue XL, Cao LX, Lu X, Wang J, Zhang LX, Zhou SN. Inhibition of Vibrio biofilm formation by a marine actinomycete strain A66. Appl Microbiol Biotechnol. 2007;76:1137-44.

22. Gunn JS, Bakaletz LO, Wozniak DJ. What's on the outside matters: the role of the extracellular polymeric substance of Gram-negative biofilms in evading host immunity and as a target for therapeutic intervention. J Biol Chem. 2016;291(24):12538-46.

23. Fleming D, Rumbaugh KP. Approaches to dispersing medical biofilms. Microorganisms. 2017;5(2):15.

\section{Publisher's Note}

Springer Nature remains neutral with regard to jurisdictional claims in published maps and institutional affiliations. 